Article Citation Format Adeyemo F.S., Mary Daniel \& Aghedo. M. (2017): Towards an Assessment of Customer Satisfaction with Nigerian Mobile Telecoms Industry and Provider Journal of Digital Innovations \& Contemp Res. In Sc., Soc. Sc., Eng \& Tech. Vol. 5, No. 4. Pp 157-161

$\begin{array}{r}\text { Article Progress Time Stamps } \\ \text { Article Type: Research Article } \\ \text { Manuscript Received: } 19^{\text {rd }} \text { Oct, } 2017 \\ \text { Review Type: Blind } \\ \text { Final Acceptance:: } 24^{\text {th }} \text { Nov. 2017 } \\ \text { Article DOI: dx.doi.org/10.22624/AIMS/DIGITAL/V5N4Px } \\ \hline\end{array}$

\title{
Towards an Assessment of Customer Satisfaction with Nigerian Mobile Telecoms Industry and Providers
}

\author{
Adeyemo F.S., Mary Daniel \& Aghedo. M. \\ Department of Business Administration \\ Caleb University \\ Imota, Lagos State, Nigeria \\ E-mail: feliciaadeyemo@yahoo.com
}

\begin{abstract}
Although a body of knowledge devoted to research on quality of service and service provisions of Mobile Service providers exist, the major focus has been on ensuring service availability while the customer satisfaction remains at the background of such studies. This limitation has therefore affected research in this domain as there are inadequate literature on customer satisfaction with the Nigerian mobile telecoms industry to consult. The majority of literature available (few in number) focuses on the study of the impact and development of the telecommunications, mobile telephony, communications, etc. This lack of adequate research in the mobile telecoms sector prevents the sector from acquiring knowledge useful for development and product/service improvements. We propose in this research a framework to address the issue of customer satisfaction with the Nigerian mobile service providers with the objective of assessing the overall customer satisfaction with Nigerian mobile telecoms industry.
\end{abstract}

Keywords: Assessment, Customer Satisfaction, Nigerian Mobile Telecoms Industry \& Providers

\section{INTRODUCTION}

Gerpott et al. (2001) wrote that since 1990s, the telecommunications sector has become an important key in the development of the economy of developed countries. This results from the saturated markets, de-regulation of telecommunications industry (removal of monopoly rights, especially enjoyed by state-owned telecoms networks), increasing number of mobile service providers, enormous technical development and intense market competition. Szyperski \& Loebbecke (1999) wrote that this increasing economic importance and benefits of telecommunications firms motivated many management scholars (especially marketing experts) to devote attention to this sector. Wilfert (1999); Gerpott (1998); and Booz. Allen and Hamilton (1995) pointed out that marketing strategies are very important in telecommunications services because once customers have subscribed to a particular telecommunications service provider, their long-term link with this provider is of greater importance to the success of the company than they are in other industry sectors. Hence, service providers need to form a continous lasting relationship with their customers to know them better and satisfy their needs adequately. 
Nigeria, a developing country, in 1992 introduced its first mobile phone services, through the joint venture between NITEL and DSL of Canada to form Mobile Telecommunications Service (MTS), (Ndukwe, 2005, pp 26). In January 2001, the regulatory body NCC, modernised and expanded the mobile telecommunications network and services by granting GSM license to three service providers; MTN Nigeria, Econet Wireless (now Vmobile), and the first national carrier, NITEL (initially MTS, privatised to form Mtel). In 2002, the second national carrier, Globacom was also granted license to commence operation. Since the launch of the GSM, the number of subscribers in Nigeria has greatly increased. Ndukwe (2005, pp 37-38, 40) reported that between 1998 and 2000, the number of mobile lines was 35,000 but grew to over 11 million as of March 2005, with a growth rate of more than a million lines annually since 2002. This translated to an increase from the total density of 0.4 lines per 100 inhabitants in 1998 to 9.47 lines per 100 inhabitants currently. Additionally, this sector has attracted an investment of over US $\$ 8$ billion and has greatly increased the number of employed people directly (those working with the GSM companies) or indirectly (this includes various levels of dealerships, cell phone vendors, repair shops, suppliers of accessories, fixed and mobile call shops and street recharge card hawkers) (Hoff, 2006). The number of the employed people is reported to be over 300,000 Nigerians in 2005 (Ndukwe, 2005). Other benefits include easy, affordable and quick access to phone by different categories of the population, reduced frequency of travelling, etc (Bhave, 2003), and all these benefits contribute to the socio- economic development of the country.

Based on the annual growth rate of the subscribers, and increasing teledensity, Nigeria is one of the fastest growing telecoms market in Africa (Hoff, 2006). Additionally, the population count of over 130 million people and GDP per capita and PPP valuation of US $\$ 1,776$ (estimated in 2005) (OECD, 2006) presents a massive growth potential for the mobile telecoms sector and the customer base is estimated to reach 23 million subscribers in 2007 and 32 million subscribers in 2009 (Hoff, 2006). This anticipated increase in the customer base will translate into better social and economic development, resulting from more financial investments from the service operators.

\section{EXISTING STUDIES AND COVERAGE}

The Global System of Mobile Communications (GSM) is a second-generation digital technology, which was originally developed in Europe and in less than ten years after the commercial launch, it developed into world's leading and fastest growing mobile standard (GSM Assoc., 2006). Lonergan et al. (2004) reported that at the beginning of 2004, there were over 1.3 billion mobile phone users worldwide and by 2007 , the demand for mobile services would have grown at an average annual rate of $9.1 \%$. The GSM Association estimates that the GSM technology is used by more than one in five people of the world's population, representing approximately $77 \%$ of the world's cellular market and is estimated to account for $73 \%$ of the world's digital market and $72 \%$ of the world's wireless market (GSM Assoc., 2006).

This growth principally results from the establishment of new networks in developing countries rather than from an increase in mobile access lines in developed countries (Turel \& Serenko 2006). African countries are actively involved in the establishment of the mobile services and specifically, Nigeria is the focus of this study. Studies conducted to explore factors affecting satisfaction, loyalty and retention in mobile telecommunications industry include: Gerpott et al. (2001) investigated customer satisfaction, loyalty and retention in the German mobile telecommunications among 684 respondents and reported that customer retention cannot be equated with customer loyalty and/or customer satisfaction, rather a two-stage causal link can be assumed in which customer satisfaction drives customer loyalty which in turn has impacts on customer retention. However, these three factors are important for superior economic success among telecommunication service providers. 
Kim et al. (2004) investigated the effects of customer satisfaction and switching barrier on customer loyalty among 350 respondents in Korea and reported that call quality, value-added services and customer support have significant impact on customer satisfaction. Thus, to maximize customer satisfaction, focus should be on service quality and customer-oriented services. Switching barrier on the other hand is affected by switching costs (e.g. loss cost, move-in cost, and interpersonal relationships) and was revealed to have an adjustment effect on customer satisfaction and customer loyalty. Serenko and Turel (2006) investigated customer satisfaction with mobiles services in Canada and reported that perceived quality and perceived value are the key factors influencing satisfaction with mobile services.

Customer care is reported to be negatively related to customer satisfaction, which means that a more satisfied customer is less prone to complain. Hence, they concluded that customer satisfaction is the only single measure that better capture the range of services, prices and quality and moreso, this measure is an important performance indicator useful for both regulators and mobile service providers. In summary, these studies support the theory that highly satisfied customers stay longer, buy more, less sensitive to price increases from their providers or price decreases from competitors.

\subsection{Research Gaps}

Despite the economic and social benefits of the mobile telecommunications to Nigerian economy and market, unlike the developed countries, there is no marketing or management research attention to this sector. However, it is probable that the mobile operators conduct satisfaction surveys and other marketing research but contact with the mobile operators for any useful information yielded no response ${ }^{1}$. This limitation affected this study in that there are currently no literature materials on customer satisfaction of the Nigerian mobile telecoms industry to consult. The majority of literature available (few in number) focuses on the study of the impact and development of the telecommunications, mobile telephony, communications, etc.

This lack of adequate research in the mobile telecoms sector may prevent it from acquiring knowledge useful for development. According to Serenko and Turel (2006), customer satisfaction measurement addresses both users and public interests and such studies can assist in economic and social development. Therefore, there is need to gain more understanding in the area of customer satisfaction. Jackson et al. (1996), Platow et al. (1997), and Homburg and Giering (2001) expressed that customer behaviours and attitudes are greatly influenced by demographic, situational, environmental and psychological factors and these factors can be used by companies and policy makers to develop strategies to meet different needs of the different customer segments. Hence, there is need to gain more understanding of the influence of these factors on customer satisfaction.

\subsection{The Thrust of Our proposed Research}

This study is to investigate the level of Nigerian customer satisfaction of the mobile telecoms services and explore the relationship between customer satisfaction and specific demographic variables. Previous studies on mobile telecommunication services suggested that network/call quality, pricing and customer care/support are important features of the mobile telecoms services (Booz, Allen \& Hamilton, 1995, Danaher \& Rust, 1996; Bolton, 1998; Gerpott, 1998; Wilfert, 1999; Kim, 2000; Gerpott et al., 2001; Lee, Lee, \& Freick, 2001). Hence, this study employs these variables in its investigation. 


\section{PROPOSED RESEARCH OBJECTIVES}

The objectives of our proposed research will be to:

1. assess the overall customer satisfaction with Nigerian mobile telecoms industry;

2. ascertain the influenced of service quality on customer satisfaction with Nigerian mobile telephone industry;

3. investigate the influence of customer support service on customer satisfaction with Nigerian mobile telephone industry;

4. find out the effect of billing systems on customer satisfaction with Nigerian mobile telephone industry ; and

5. verify the relationship between certain demographic variables (age, gender, type of employment and location) and customer satisfaction with Nigerian mobile telephone industry.

\subsection{Research Questions}

The following research questions will guide our research design

1. What is the overall customer satisfaction of the Nigerian mobile telecoms industry

2. Does service quality influencing customer satisfaction with Nigerian mobile telephone industry

3. Does customer support service influence customer satisfaction with Nigerian mobile telephone industry?

4. Does billing systems influence customer satisfaction with Nigerian mobile telephone industry?

5. Are there any relationship between certain demographic variables (age, gender, type of employment and location) and customer satisfaction with Nigerian mobile telephone industry?

\subsection{Research Hypotheses}

In our study, the following hypothesis will be tested

$\mathrm{H}_{\text {. }} \quad$ There is no strong relationship between network quality and customer satisfaction with Nigerian mobile telephone industry.

$\mathrm{H}_{2} \quad$ There is no strong relationship between billing and customer satisfaction with Nigerian mobile telephone industry.

$\mathrm{H}_{3}$ There is no strong relationship between customer care support and customer satisfaction with Nigerian mobile telephone industry.

$\mathrm{H}_{4} \quad$ There is a strong relationship between certain demographic variables and customer satisfaction

\subsection{Scope of the study}

This is restricted to mobile users in Lagos, Nigeria, the commercial centre of the country. The time frame for this study is 2018. The content in focus is network quality, customers care support, billing system and customer satisfaction.

\subsection{Significance of the study.}

This study is significant in several ways. It will help mobile operators to know the level to which their customers are satisfied with the services render to them. This will help the practitioners to deploy strategies in order to improve the level of service render to users of GSM. 


\section{EXPECTED CONTRIBUTIONS TO KNOWLEDGE}

It is expected that upon completion of the research, the researchers would have developed a reference material for further studies in the domain while identifying socio-economic and other factors affecting the provision of efficient services to consumers by mobile service providers in Nigeria.

\section{BIBLIOGRAPHY}

1. Bhave, A., 2002- "Customer satisfaction measurement", Quality and Productivity Journal, Symphony Technologies Pvt Ltd, Erendavane, India.

2. Bolton, R.N. (1998) - A dynamic model of the duration of the customer's relationship with a continuous service provider: the role of satisfaction”, Marketing Science, Vol. 17 No. 1, pp. 4565.

3. Booz Allen, \& Hamilton (1995)- Mobilfunk. Frankfurt/M.: IMK.

4. Danaher, P. J., \& Rust, R. T. (1996) - Indirect financial benefits from service quality. Quality Management Journal, 3(2), pp.63-75.

5. Gerpott, T. J. (1998)- Wettbewerbsstrategien im Telekommunikationsmarkt (3rd ed.). Stuttgart: Schaffer-Poeschel.

6. Gerpott, T.J., Rams, W., and Schindler, A., (2001) - "Customer retention, loyalty, and satisfaction in the German mobile telecommunications market, Telecommunications Policy, Vol. 25 No. 4, pp.249 - 269.

7. GSM Association (2006) - www.gsmworld.com

8. Homburg, C., \& Bruhn, M. (1998). Kundenbindungsmanagement - Eine EinfuK hrung in die theoretischen and praktischen Problemstellungen. In M. Bruhn, \& C. Homburg (Eds.), Handbuch Kundenbindungsmanagement (pp. 3\}35).Wiesbaden: Gabler.

9. Jackson, L.A., Sullivan, L.A., Harnish, R. and Hodge, C.N. (1996)-"Achieving positive social identity: social mobility, social creativity, and permeability of group boundaries", Journal of Personality and Social Psychology, Vol. 70, pp. 241-54.

10. Kim, H. (2000) - The churn analysis and determinants of customer loyalty in Korean mobile phone. Korean Information Society Review, 2000, 1-18.

11. Lee, J., Lee, J., \& Freick, L. (2001) - The impact of switching costs on the customer satisfactionloyalty link: Mobile phone service in France. Journal of Services Marketing, 15(1), 35-

12. Ndukwe, Ernest (2005) - Country experience in telecom market reforms in Nigeria. CEO, Nigerian Communication Commission, July 2005. www.ncc.gov.ng.

13. Platow, M. J., Harley, K., Hunter, J. and Banning, P. (1997) - "Interpreting in-group-favoring allocations in the minimal group paradigm", British Journal of Social Psychology, Vol. 36, pp. $107-17$.

14. Szyperski, N., \& Loebbecke, C. (1999). Telekommunikationsmanagement (TKM) als betriebswirtschaftliche Spezialdisziplin. Die Betriebswirtschaft, 59, 481$\} 495$.

15. Turel, O. and Serenko, A. (2006) - Satisfaction with mobile services in Canada: An empirical investigation, Telecommunications Policy 30 (2006), pp.314-331, 2006.

16. Wilfert, A. (1999)- Der Wettbewerb auf dem Mobilfunkmarkt in Deutschland. In D. Fink, \& A. Wilfert (Eds.), Handbuch Telekommunikation und Wirtschaft (pp. 187\}202). MuK nchen: Vahlen. 